\title{
Effectiveness of pH and Butylated Hydroxyanisole (BHA) on Fungicidal Activity of Certain Fungicides for Controlling Green and Blue Mold Diseases on Orange Fruits \\ Sameer, W. M. and I. S. Ibrahim \\ Department of Plant Protection, Faculty of Agriculture, Al-Azhar University, Nasr City, Cairo, Egypt \\ Corresponded author: Sameer, W. M. Dr. Wael_Sameer@yahoo.com
}

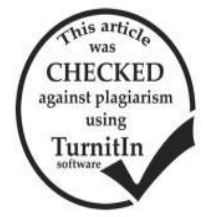

ABSTRACT

Green and blue molds caused by Penicillium digitatum and P. italicum, respectively, are the major postharvest cause of orange fruit decay, resulting in economic losses in the citrus industry. Four fungicides (i.e. boscalid, kresoxim-methyl, boscalid+kresoxim-methyl and cyprodinil+ fludioxonil) and the antioxidant butylated hydroxyanisole (BHA) were evaluated separately and in mixtures against $P$. digitatum and $P$. italicum causing green and blue mold diseases of navel orange fruits, respectively. The in vitro studies showed that higher (8-11) and lower (3-5) $\mathrm{pH}$ values reduced the growth of $P$. digitatum and $P$. italicum. Also, the results showed that the premixed fungicide formulations were more efficient in inhibiting the mycelial growth of fungi than individual forms. Both fungi tolerated high concentrations of BHA. The potency of fungicides and BHA against fungi growth was interestingly increased at $\mathrm{pH} 3$ and 9. Also, the fungitoxic activities of fungicides were increased by adding BHA to fungicide-amended medium. The in vivo studies illustrated that all the separated fungicide treatments, particularly the mixtures of them, effectively controlled the diseases, while the separate BHA treatments slightly reduced the incidence of diseases. Also, the addition of BHA to the fungicides greatly increased their efficiencies against the incidence of diseases. Moreover, the potency of fungicide and BHA was considerably increased at $\mathrm{pH}$ values of 3 and 9.

\section{INTRODUCTION}

Citrus fruits, either used freshly or as juice, have essential factors responsible for their nutritional and health benefits such as amino acids, organic acids, sugars, phenolics, vitamins, carotenoids and volatiles (CerdanCalero et al., 2012). However, these fruits during postharvest handling and storage, are susceptible to some pathogens including Penicillium digitatum (Pers.: Fr.) Sacc. and Penicillium italicum Wehmer, which are the causal green and blue mold diseases, respectively, and thus caused considerable economic losses (Palou, 2014). During storage, the disease may result in complete damage collapse and liquefaction of infected fruit. Juices dripping from infected fruit can readily spread the pathogen to healthy fruit (Eckert and Eaks, 1989). Good practices such as avoiding injury during harvest and transportation as well as sanitation of packing- and store- houses, can reduce postharvest decay.

For postharvest pathogenic fungi, Prusky et al. (2004) stated that pathogens may enhance their virulence by locally modulating the ambient $\mathrm{pH}$ of host either up or down. Pitt and Hocking (1997) illustrated that most molds can grow in a wide range of $\mathrm{pH}$ (3-8), but most of them prefer acidic $\mathrm{pH}$. Also, Smilanick et al. (2005) reported that the $\mathrm{pH}$ above 8 inhibits $P$. digitatum growth.

Several fungicides either separately as thiabendazole and imazalil (Smilanick et al., 2008 and Sanchez-Torres and Tuset, 2011), boscalid (Serey et al., 2007 and Malandrakis et al., 2017) and kresoxim-methyl (Jae-Wook et al., 2001 and Malandrakis et al., 2017) or premixed as boscalid + kresoxim-methyl (Serey et al., 2007; Zhang et al., 2007 and 2008 and Malandrakis et al., 2017) and cyprodinil + fludioxonil (Errampalli and Crnko, 2004; Serey et al., 2007 and Sallato et al., 2007) have been used to control postharvest diseases.

Owing to their efficacy and low cost, antioxidants including phenolic derivatives such as butylated hydroxyanisole (BHA) are extensively used to control a wide range of plant diseases (Giridhar and Reddy, 2001; Rajkumar et al., 2008 and Abdel-Monaim and Ismail, 2010).
The effect of $\mathrm{pH}$ on the antimicrobial activity of fungicides or BHA is highly dependent upon the tested fungi. Smilanick et al. (2008) found that $\mathrm{pH}$ 8-9 enhanced the fungitoxic activity of fludioxonil against $P$. digitatum. The antifungal effect of BHA on Penicillium spp. at pH 3.5 was greater than at $\mathrm{pH} 7$ or $\mathrm{pH} 5.5$ (Ghadimipour and Sedigh-Eteghad, 2015).

On the other hand, the addition of BHA improved the fungitoxic activity of imazalil against Colletotrichum musae (Khan et al., 2001), fluconazole (Simonetti et al., 2002), ticonazole (Simonetti et al., 2003) against Candida albicans and Escherichia coli, iprodion, myclobutanil, prochloraz, tetraconazole and trifloxystrobin against $P$. digitatum (Khalifa and Sameer, 2014).

The aim of this study was to evaluate the fungicidal activity of certain fungicides as affected by definite $\mathrm{pH}$ values and the antioxidant butylated hydroxyanisole (BHA) in controlling the green and blue mold diseases on orange fruits.

\section{MATERIALS AND METHODS}

The present work was carried out in the laboratory of Plant Protection Dept., Faculty of Agriculture, ALAzhar University, Cairo, Egypt during 2018.

Fungi: Identified isolates of Penicillium digitatum and $P$. italicum, the causal agents of green and blue molds citrus fruits, respectively, were obtained from Plant Disease Institute, Agricultural Research Center, Giza.

Fungicides: Four commercial fungicides, represent different chemical groups were selected for the present work. These fungicides are: boscalid (Cantus $50 \% \mathrm{WG}$ ), kresoxim-methyl (Sevron $50 \% \mathrm{WG}$ ), the premixed formulation of $20 \%$ boscalid $+10 \%$ kresoxim-methyl (Collis $30 \%$ SC) and the premixed formulation of $37.5 \%$ cyprodinil $+25 \%$ fludioxonil (Switch $62.5 \% \mathrm{WG}$ ).

Antioxidant: Butylated hydroxyanisole (BHA) $\mathrm{C}_{11} \mathrm{H}_{16} \mathrm{O}_{2}$ (99\% w/w).

In vitro fungitoxicity test

A study was conducted to estimate the fungicidal activity of the tested fungicides and antioxidant either separately under defined $\mathrm{pH}$ values or in mixtures under native $\mathrm{pH}$ medium. The effect of $\mathrm{pH}$ on mycelial growth of 
fungi was examined by adjusting (PDA) at 3.0 to 11.0 using $1.0 \mathrm{~N} \mathrm{NaOH}$ or $\mathrm{HCl}$ prior to autoclaving, the degree of $\mathrm{pH}$ was determined by the $\mathrm{pH}$ meter (Turkkan and Erper, 2014). The fungicides were diluted in sterile distilled water, then added to cooled PDA medium at concentrations of $0.001,0.005,0.01,0.05,0.1,0.5,1.0,2.5$, 5.0 and $10.0 \mu \mathrm{g}$ a.i. / $\mathrm{ml}$ for each, whereas antioxidant was evaluated at concentrations of 10.0, 25.0, 50.0, 75.0, 100, $150,200,250,300,350,400,450$ and $500 \mu \mathrm{g}$ a.i. / ml. The influence of $\mathrm{pH}$ on the fungicidal activity of the tested fungicides and BHA was evaluated in these concentrations in buffered PDA at $\mathrm{pH} 3$ or 9. In other trials, native PDA media amended with different concentrations of each fungicide were further amended with 25 or $50 \mu \mathrm{g} / \mathrm{ml}$ antioxidant. The poisoned media were poured in plates $(9$ $\mathrm{cm}$ diameter), whereas plates of control treatment contained compounds - free medium. All plates were inoculated by $0.4 \mathrm{~cm}$ diameter disk, removed from 7 dayold culture of the fungus, and incubated for 7 days at $25^{\circ} \mathrm{C}$. Each treatment was replicated four times. Growth on the each treatment amended medium was determined by measuring the colony diameter $(\mathrm{cm})$. The percentage of growth inhibition was calculated relative to the control treatment. The effective concentration giving $50 \%$ linear growth inhibition $\left(\mathrm{EC}_{50}\right)$ was determined by regression analysis of the log probit transformed data (Finney, 1971).

\section{In vivo test}

This trial was conducted to investigate the fungicidal activity of the tested fungicides and antioxidant either separately under defined $\mathrm{pH}$ values or in mixtures under native $\mathrm{pH}$ for controlling the incidence of artificial infection with green and blue molds on navel orange under laboratory conditions. Healthy uniform navel oranges were used in this trial. The fruits were washed with soap, rinsed with fresh water, and washed again with $70 \%$ ethanol for surface sterilization. After drying, the fruits were inoculated artificially with $P$. digitatum or $P$. italicum. Inoculation was performed according to Eckert and Kolbezen (1977) by making a scratch $1.0 \mathrm{~cm}$ long and 0.1 $\mathrm{mm}$ deep in the rind on both sides of each fruit and then applying dry spores dust to the scratches with a small brush. Twenty four hours after inoculation, orange fruits were treated with the tested fungicides and BHA and their mixtures by using dipping method in the solutions for 30 sec. To determine the influence of $\mathrm{pH}$ on the fungicidal activity of fungicides or BHA against incidence of green and blue molds on fruits, these compounds were evaluated separately at concentrations (1000, 1500 and $2000 \mu \mathrm{g}$ a.i. / $\mathrm{ml})$ at 3 or $9 \mathrm{pH}$. In other trial, fungicides and BHA were evaluated either separately or in mixtures at the same concentrations in native $\mathrm{pH}$. All treatments were replicated 3 times and each replicate contained 8 oranges. Other fruits were dipped in water only as control treatments. The treated fruits were air-dried, and inspected for decay 15 days after storage in plastic bags at $25^{\circ} \mathrm{C}$. The efficacy of each treatment was determined according to the equation described by Samoucha and Cohen (1989) as follows:

Percentage of control efficacy $(P C E)=100(1-x / y)$,

Where, $x=$ number of decayed fruits in treatment and $y=$ number of decayed fruits in control treatment. The results were statistically analyzed according to Snedecor and Cochran (1969).

\section{RESULTS AND DISCUSSION}

\section{In vitro fungitoxicity tests}

Effect of pH on mycelial growth of the tested fungi:

The results in Table (1) show that both $P$. digitatum and $P$. italicum may differentially grow under acidic and basic $\mathrm{pH}$ values. Although $\mathrm{pH} 6$ and 7 did not negatively affect the mycelial growth of these fungi, higher (8-11) and lower (3-5) values considerably reduced this growth. The higher $\mathrm{pH} 8,9,10$ and 11 reduced the growth of $P$. digitatum and $P$. italicum to 7.7, 4.8, 4.0 and $3.5 \mathrm{~cm}$ and to $7.2,5.0,3.8$ and $3.5 \mathrm{~cm}$, respectively, On the other hand, the lower $\mathrm{pH} 5,4$ and 3 reduced the growth of fungi to 7.8, 7.5 and $4.6 \mathrm{~cm}$ and to $7.9,7.8$ and $5.0 \mathrm{~cm}$, respectively. The results are compatible with those of Eckert and Eaks (1989) who found that $\mathrm{pH}$ values above 8.5 inhibit the germination and growth of $P$. digitatum. Similarly, Smilanick et al. (2006 and 2008) found that germination of conidia of $P$. digitatum was more than $95 \%$ at $\mathrm{pH} 4-7$, but at $\mathrm{pH} 8$, germination reduced to $50 \%$ and completely inhibited at $\mathrm{pH} 9$.

\begin{tabular}{|c|c|c|}
\hline \multirow{2}{*}{ pH } & \multicolumn{2}{|c|}{ Radial growth of fungi $(\mathrm{cm})$} \\
\hline & Penicillium digitatum & Penicillium italicum \\
\hline 3 & 4.6 & 5.0 \\
\hline 4 & 7.5 & 7.8 \\
\hline 5 & 7.8 & 7.9 \\
\hline 6 & 9.0 & 9.0 \\
\hline 7 & 9.0 & 9.0 \\
\hline 8 & 7.7 & 7.2 \\
\hline 9 & 4.8 & 5.0 \\
\hline 10 & 4.0 & 3.8 \\
\hline 11 & 3.5 & 3.5 \\
\hline
\end{tabular}

\section{Sensitivity of the tested fungi to the fungicides and} BHA

Results in Table (2) show the efficiency of the tested fungicides and BHA against growth of $P$. digitatum and $P$. italicum. Based on $\mathrm{EC}_{50}$ values, mixtures of cyprodinil + fludioxonil and boscalid + kresoxim-methyl fungicides are more effective in inhibiting the mycelial growth of $P$. digitatum $\left(\mathrm{EC}_{50}\right.$ values were 0.058 and $0.086 \mu \mathrm{g}$ a.i. / $\mathrm{ml}$, respectively) and $P$. italicum $\left(\mathrm{EC}_{50}\right.$ values were 0.053 and $0.064 \mu \mathrm{g}$ a.i. / $\mathrm{ml}$, respectively) than the single fungicides kresoxim-methyl and boscalid $\left(\mathrm{EC}_{50}\right.$ against $P$. digitatum were 0.594 and $1.32 \mu \mathrm{g}$ a.i. / $\mathrm{ml}$, respectively, and against $P$. italicum were 0.419 and $1.18 \mu \mathrm{g}$ a.i. / $\mathrm{ml}$, respectively). These results are in agreement with those of Jae-Wook et al. (2001) who found that the $\mathrm{EC}_{50}$ values of kresoxim-methyl were 0.04-0.16 and 0.08$0.16 \mu \mathrm{g} / \mathrm{ml}$ against mycelial growth of $P$. digitatum and $P$. italicum, respectively. Moreover, Karaoglanidis et al. (2011) showed that $P$. expansum was sensitive to cyprodinil and fludioxonil with mean $\mathrm{EC}_{50}$ values of 0.55 and $0.08 \mu \mathrm{g} / \mathrm{ml}$, respectively. Similarly, Helalia and Sameer (2014) indicated that the $\mathrm{EC}_{50}$ value of fludioxonil to $P$. digitatum was $0.06 \mu \mathrm{g} / \mathrm{ml}$. Our results indicated that the $\mathrm{EC}_{50}$ values reduced by mixtures of 
fungicides comparing with the fungicides alone. These findings are in agreement with other previous studies (Errampalli and Crnko, 2004; Serey et al., 2007 and Zhang et al., 2007 and 2008).

The different modes of action of the tested fungicides (boscalid inhibits succinate dehydrogenase in the cell respiration process, kresoxim-methyl acts at the quinone binding site of the cytochrome bc1 complex in the mitochondrial cell membrane, cyprodinil inhibits excretion of hydrolytic enzymes and methionine biosynthesis in fungal cells, fludioxonil inhibits transport-associated phosphorylation of glucose as well as prevents glycerol synthesis) and their different chemical structures as well as the nature of the target fungus may be contributory factors affecting their fungicidal activities.

The data represented in Table (2) also show that the tested fungi capable to tolerate high concentrations of BHA, whereas its $\mathrm{EC}_{50}$ values for $P$. digitatum and $P$. italicum were 281.73 and $267.14 \mu \mathrm{g} / \mathrm{ml}$, respectively. In this respect, Thompson (1997) reported that the effective concentrations of BHA that reduced radial growth of Penicillium spp. by $50 \%\left(\mathrm{EC}_{50}\right)$ were 100 $275 \mu \mathrm{g} / \mathrm{ml}$. Khalifa and Sameer (2014) found that the $\mathrm{EC}_{50}$ value of BHA was $256.21 \mu \mathrm{g} / \mathrm{ml}$ for P. digitatum. Ghadimipour and Sedigh-Eteghad (2015) demonstrated that the minimum inhibitory concentration (MIC) of BHA against Penicillium spp. was $320 \mu \mathrm{g} / \mathrm{ml}$.
Effect of $\mathrm{pH}$ on fungicidal activity of the tested fungicides and BHA:

Data tabulated in Table (2) clearly indicate that the $\mathrm{EC}_{50}$ values either of fungicides or BHA in buffered PDA at $\mathrm{pH} 3$ or 9 were lower than those determined in native PDA indicating that such $\mathrm{pH}$ values enhanced the potency of fungicides and BHA against growth of $P$. digitatum and $P$. italicum. This enhancement effect differed according to compound concentration and $\mathrm{pH}$ value.

Concerning fungicides, their efficiencies increased in buffered PDA at $\mathrm{pH} 9$ more than $\mathrm{pH}$ 3. For example, efficiency of boscalid against $P$. digitatum and $P$. italicum increased by 2.13 - and 2.88- fold at $\mathrm{pH} 9$ comparing to 1.67 and 2.41- fold at $\mathrm{pH} 3$, respectively. The premixed fungicide, boscalid + kresoxim-methyl alone had $\mathrm{EC}_{50}$ values of 0.086 and $0.064 \mu \mathrm{g} / \mathrm{ml}$ for $P$. digitatum and $P$. italicum, respectively, which decreased to 0.039 and 0.034 and to 0.046 and $0.041 \mu \mathrm{g} / \mathrm{ml}$ in buffered PDA at $\mathrm{pH} 9$ and 3, respectively, indicating that the fungitoxic activity of this fungicide increased by 2.21 - and 1.88 -fold and by 1.87 - and 1.56-fold, respectively. The results obtained are in agreement with those obtained by other investigators. Holmes and Eckert (1999) found that the $\mathrm{EC}_{50}$ value for imazalil against $P$. digitatum was 4.66 and $0.88 \mu \mathrm{g} / \mathrm{ml}$ at $\mathrm{pH} 5.1$ and 5.7, respectively. Imazalil effectiveness against $P$. digitatum was significantly better at $\mathrm{pH} 7.5$ compared at $\mathrm{pH} 4$ (Smilanick et al., 2005). Also, the $\mathrm{EC}_{95}$ value for fludioxonil against $P$. digitatum was $0.028 \mathrm{mg} / \mathrm{L}$ at $\mathrm{pH} 9$, however, it was 0.251 $\mathrm{mg} / \mathrm{L}$ at pH 4 (Smilanick et al., 2008).

Table 2. $\mathrm{EC}_{50} *$ values $(\mu \mathrm{g}$ a.i. / $\mathrm{ml}$ ) of the tested fungicides separately and under definite $\mathrm{pH}$ values and the antioxidant BHA against mycelial growth of the two fungi.

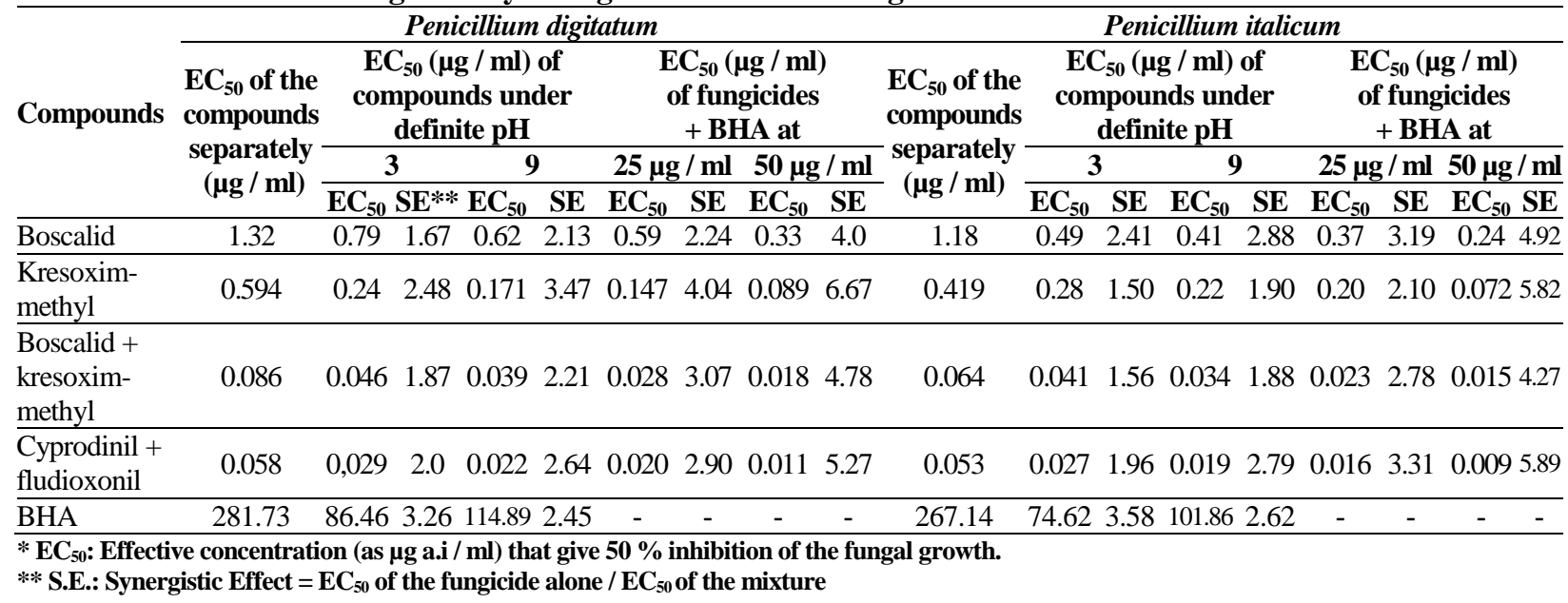

In view of BHA efficiency, the results showed that its potency against $P$. digitatum and $P$. italicum increased at $\mathrm{pH} 3$ more than $\mathrm{pH}$ 9. For example, BHA efficiency increased by 3.26- and 2.45- and by 3.58- and 2.62- fold at $\mathrm{pH} 3$ and 9, respectively. These data are in agreement with other previous studies. Conidial germination for Penicillium species was significantly reduced in the presence of $100 \mu \mathrm{g} / \mathrm{ml}$ of BHA at $4,6,8$ and $10 \mathrm{pH}$ (Thompson et al., 1993). Arroyo (2003) reported that the in vitro antifungal activity of BHA against Penicillium spp. was increased as $\mathrm{pH}$ value decreased. Ghadimipour and Sedigh-Eteghad (2015) found that the MIC values of BHA for Penicillium sp. at $\mathrm{pH} 5.5$ reduced to half and at $\mathrm{pH} 3.5$ reduced to one-sixth.

\section{Effect of BHA on fungicidal activity of the tested fungicides:}

The results in Table (2) clearly indicate that the fungitoxic activities of fungicides greatly increased by adding BHA to fungicide-amended medium and this observation was BHA concentration and type of the examined fungicide dependent.

For example, boscalid efficiency against both fungi markedly increased as affected by BHA addition. Such increment reached 2.24- and 4.0- fold with $P$. digitatum and reached 3.19- and 4.92- fold with P. italicum when BHA was added at 25 and $50 \mu \mathrm{g} / \mathrm{ml}$, respectively. Concerning the boscalid + kresoxim-methyl efficiency, the results showed that this compound had $\mathrm{EC}_{50} 0.086$ and 
$0.064 \mu \mathrm{g} / \mathrm{ml}$ against $P$. digitatum and $P$. italicum, respectively. Interestingly, its fungicidal activity against both fungi was increased by 3.07- and 4.78- fold and by 2.78- and 4.27- fold, respectively, when 25 and $50 \mu \mathrm{g} / \mathrm{ml}$ of BHA were added, respectively, to fungicide-amended medium. The $\mathrm{EC}_{50}$ values of (cyprodinil + fludioxonil) alone for $P$. digitatum and $P$. italicum were 0.058 and $0.053 \mu \mathrm{g} / \mathrm{ml}$, respectively, and became 0.011 and 0.009 $\mu \mathrm{g} / \mathrm{ml}$, respectively, when $50 \mu \mathrm{g} / \mathrm{ml}$ of BHA was added to the medium, indicating that its fungitoxic action increased by 5.27 - and 5.89- fold, respectively. These findings are in agreement with other previous studies (Khan et al., 2001; Simonetti et al., 2002 and 2003; Ali, 2008 and Khalifa and Sameer, 2014).

\section{In vivo studies}

\section{Effect of pH on green and blue mold diseases:}

The results in Table (3) show that $\mathrm{pH} 3$ and 9 slightly controlled the incidence of green and blue molds on orange fruits by $20.83 \%$ and $29.17 \%$ and by $25.0 \%$ and $37.5 \%$, respectively, and basic $\mathrm{pH}$ value was more effective than acidic $\mathrm{pH}$. These findings are in agreement with other previous studies (Eckert and Eaks, 1989; Pitt and Hocking, 1997; Smilanick et al., 2005, 2006 and 2008; Guo et al., 2014; Turkkan and Erper, 2014 and Ghadimipour and Sedigh-Eteghad, 2015).

Effect of fungicides and BHA on green and blue mold diseases:

Fungicidal efficacy of the tested fungicides and BHA at 1000, 1500 and $2000 \mu \mathrm{g} / \mathrm{ml}$ were evaluated separately for controlling green and blue molds on orange fruits. Results in Table (3) reveal that the green and blue mold diseases are sufficiently controlled only at 1500 and $2000 \mu \mathrm{g} / \mathrm{ml}$ of the tested fungicides. Cyprodinil + fludioxonil, boscalid + kresoxim-methyl, kresoxim-methyl and boscalid all at $2000 \mu \mathrm{g} / \mathrm{ml}$ caused the corresponding controlling rates of $95.83,91.67,75.00$ and $66.67 \%$ for green mold and of 95.83, 95.83, 75.00 and $70.83 \%$ for blue mold. The results indicated that the PCE values for green and blue mold diseases on orange fruits were highly significant with fungicide mixtures comparing with separated fungicides. The above results confirmed the in vitro experiments and are in agreement with those previously reported (Jae-Wook et al., 2001; Errampalli and Crnko, 2004; Sallato et al., 2007; Serey et al., 2007; Zhang et al., 2007 and 2008 and Malandrakis et al., 2017). The mixture of boscalid + kresoxim-methyl showed significant control efficacy against strawberry grey mold caused by Botrytis cinerea than boscalid or kresoxim-methyl separately (Zhang et al., 2008). Also, the maximum curative action against $P$. expansum was obtained when both cyprodinil and fludioxonil were applied in combination (Serey et al., 2007).

Results in Table (3) also show that BHA slightly controlled the incidence of green and blue mold diseases on orange fruits as PCE values for both diseases did not exceed $25 \%$ at the high concentration $(2000 \mu \mathrm{g} / \mathrm{ml})$. Such findings are in agreement with those previously reported. Ali (2008) found that BHA at 5 and $10 \mu \mathrm{g} / \mathrm{ml}$ had no fungicidal activity against fusarium wilt, dampingoff and early blight diseases on tomato plants comparing with the control treatment. Khalifa and Sameer (2014) found that BHA slightly reduced the incidence of green mold on orange fruits.

\section{Synergistic effect of $\mathrm{pH}$ to fungicides and BHA against green and blue mold diseases on orange fruits:}

Data tabulated in Table (3) clearly indicate that the tested $\mathrm{pH}$ values ( 3 and 9) markedly enhanced the potency of fungicides or BHA for controlling green and blue mold diseases on orange fruits and such fungicidal effect of fungicides was obviously observed at $\mathrm{pH} 9$. For example, PCE values of boscalid and cyprodinil + fludioxonil at $1000 \mu \mathrm{g} / \mathrm{ml}$ for green mold disease were 25.00 and $54.17 \%$ which increased to 54.17 and 66.67 $\%$ at $\mathrm{pH} 3$ and to 70.83 and $83.33 \%$ at $\mathrm{pH} 9$. In the case of blue mold disease, the corresponding PCE values of the two fungicides at the same concentration were 33.33 and $62.50 \%$ which increased to 54.17 and $70.83 \%$ at pH 3 and to 66.67 and $83.33 \%$ at pH 9. These results mean that basic or acidic $\mathrm{pH}$ increased the efficiencies of fungicides against the incidence of green and blue mold on orange fruits and basic $\mathrm{pH}$ was more effective than the acidic $\mathrm{pH}$. These results are compatible with the in vitro tests and are in agreement with those previously reported (Holmes and Eckert, 1999 and Smilanik et al., 2005 and 2008). Smilanik et al. (2008) suggested that the fungicidal activity of fludioxonil against $P$. digitatum increased at $\mathrm{pH} 8-9$.

On the other side, the results in Table (3) indicate that the efficiency of BHA for controlling green and blue mold diseases increased at $\mathrm{pH} 3$ more than at $\mathrm{pH} 9$. For example, 1000, 1500 and $2000 \mu \mathrm{g} / \mathrm{ml}$ of BHA alone exhibited 8.33, 12.50 and 25.00 PCE, respectively, for green mold disease which became 41.67, 50.00 and $58.33 \%$ at $\mathrm{pH} 3$ and 33.33, 37.50 and $54.17 \%$ at $\mathrm{pH} 9$, respectively. For blue mold disease, BHA at the same concentrations resulted in PCE values of $12.50,20.83$ and $25.00 \%$ which recorded 45.83, 50.00 and $54.17 \%$ at pH 3 and 45.83, 45.83 and 50.00 $\%$ at $\mathrm{pH} 9$, respectively. These results confirmed the in vitro tests and are in agreement with those previously reported (Thompson et al., 1993; Arroyo, 2003 and Ghadimipour and Sedigh-Eteghad, 2015).

Regarding to this finding, Griffin (1994) stated that the influence of $\mathrm{pH}$ on fungal growth is complex and dependent upon the ionization of acids or bases in the medium in which the fungus resides, and that $\mathrm{pH}$ can alter membrane potentials that change the permeability of fungal membranes to many substances, including fungicides and BHA. Hwang and Klotz (1938) stated that hydrogen and hydroxyl ion concentrations were important factors in the inhibitory or lethal activity of many compounds to fungal spores.

Synergistic effect of BHA on fungicides against green and blue mold diseases on orange fruits

Results in Table (3) indicate that the addition of BHA to the fungicides greatly increased their efficiencies against the incidence of green and blue mold diseases. The addition of $1500 \mu \mathrm{g} / \mathrm{ml}$ of BHA to the tested fungicidal treatments, boscalid, kresoximmethyl, boscalid + kresoxim-methyl and cyprodinil + fludioxonil (each at $1000 \mu \mathrm{g} / \mathrm{ml}$ ), raised their fungicidal activities against green mold disease from $25.00,37.50,45.83$ and $54.17 \%$ to $70.83,75.00,79.17$ and $83.33 \%$, respectively, and raised their fungicidal activities against blue mold disease from 33.33, 41.67, 50.00 and $62.50 \%$ to $75.00,79.17,91.67$ and $91.67 \%$, respectively. Moreover, the fungicidal activities of the 


\section{J. Plant Prot. and Path., Mansoura Univ., Vol. 10 (4), April, 2019}

tested fungicides, when applied at $2000 \mu \mathrm{g} / \mathrm{ml}$, ranged from 66.67 to $95.83 \%$ and from 70.83 to $95.83 \%$ against green and blue mold diseases, respectively,

which raised to $91.67-100 \%$ for both diseases. These data are in agreement with other previous studies.

Table 3. Effect of definite pH values and the antioxidant BHA on PCE of certain fungicides against incidence of green and blue mold diseases on orange fruits.

\begin{tabular}{|c|c|c|c|c|c|c|c|c|c|c|c|c|c|c|c|}
\hline \multirow{4}{*}{ Treatments } & \multirow{4}{*}{$\begin{array}{l}\text { Conc } \\
\mu \mathrm{g} / \mathrm{ml}\end{array}$} & \multicolumn{14}{|c|}{ Percentage of control efficiency (PCE) } \\
\hline & & \multicolumn{6}{|c|}{ Green mold } & \multicolumn{7}{|c|}{ Blue mold } & \multirow{3}{*}{$\begin{array}{c}\text { L.S.D. } \\
\text { at } 5 \\
\%\end{array}$} \\
\hline & & \multirow{2}{*}{$\begin{array}{l}\text { Separated } \\
\text { treatment }\end{array}$} & \multicolumn{2}{|c|}{$\begin{array}{l}\text { Candidate } \\
\text { pH degrees }\end{array}$} & \multicolumn{3}{|c|}{$\begin{array}{l}\text { Candidate BHA } \\
\text { concentrations }\end{array}$} & \multirow{2}{*}{$\begin{array}{c}\text { L.S.D. } \\
\text { at } 5 \\
\%\end{array}$} & \multirow{2}{*}{$\begin{array}{l}\text { Separated } \\
\text { treatment }\end{array}$} & \multicolumn{2}{|c|}{$\begin{array}{l}\text { Candidate } \\
\text { pH degrees }\end{array}$} & \multicolumn{3}{|c|}{$\begin{array}{l}\text { Candidate BHA } \\
\text { concentrations }\end{array}$} & \\
\hline & & & 3 & 9 & $\begin{array}{c}1000 \\
\mu \mathrm{g} / \mathrm{ml}\end{array}$ & $\begin{array}{c}1500 \\
\mu \mathrm{g} / \mathrm{ml}\end{array}$ & $\begin{array}{c}2000 \\
\mu \mathrm{g} / \mathrm{ml}\end{array}$ & & & 3 & 9 & $\begin{array}{c}1000 \\
\mu \mathrm{g} / \mathrm{ml}\end{array}$ & $\begin{array}{c}1500 \\
\mu \mathrm{g} / \mathrm{ml}\end{array}$ & $\begin{array}{c}2000 \\
\mu \mathrm{g} / \mathrm{ml}\end{array}$ & \\
\hline $\mathrm{pH} 3$ & & 20.83 & - & - & - & - & - & - & 25.00 & - & - & - & 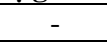 & 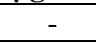 & - \\
\hline 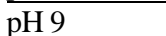 & & 29.17 & - & - & - & - & - & - & 37.50 & - & - & - & - & - & - \\
\hline \multirow{3}{*}{ Boscalid } & 10 & 25.00 & 54.17 & 70.83 & 58.33 & 70.83 & 83.33 & 10.36 & 33.33 & 54.17 & 66.67 & 66.67 & 75.00 & 79 & 7.33 \\
\hline & 1500 & 50.00 & 62.50 & 17 & 66.67 & 83.33 & 91.67 & 8.33 & 50 & 66.67 & 75.00 & 70.83 & & & .58 \\
\hline & 2000 & 66.67 & 70.83 & 87.50 & 79.17 & 91.67 & 95.83 & 8.24 & 70.83 & 79.17 & 91.67 & 79.17 & 91.67 & 95 & 8.03 \\
\hline \multirow{3}{*}{$\begin{array}{l}\text { Kresoxim- } \\
\text { methyl }\end{array}$} & 1000 & 37.50 & 50.00 & 75.00 & 58.33 & 75.00 & 79.17 & 7.62 & 41.67 & 54.17 & 79.17 & 70.83 & 79.17 & 87.50 & 7.49 \\
\hline & 1500 & 66.67 & 75.00 & 83.33 & 75.00 & 87.50 & 91.67 & 8.05 & 70.83 & 79.17 & 83.33 & 83.33 & 87.50 & 95.83 & 8.09 \\
\hline & 2000 & 75.00 & 83.33 & 91.67 & 83.33 & 91.67 & 95.83 & 7.78 & 75.00 & 79.17 & 87.50 & 87.50 & 91.67 & 95.83 & 8.52 \\
\hline \multirow{3}{*}{$\begin{array}{l}\text { Boscalid + } \\
\text { kresoxim- } \\
\text { methyl }\end{array}$} & 1000 & 45.83 & 58.33 & 83.33 & 70.83 & 79.17 & 87.50 & 8.27 & 50.00 & 62.50 & 83.33 & 75.00 & 7 & 95 & 15 \\
\hline & 1500 & 75.00 & 79.17 & 87.50 & 87.50 & 91.67 & 100.0 & 6.15 & 87.50 & 87.50 & 95.83 & 91.67 & 91.67 & 95.83 & 7.03 \\
\hline & 2000 & 91.67 & 95.83 & 95.83 & 95.83 & 100.0 & 100.0 & 7.91 & 95.83 & 100.0 & 100.0 & 100.0 & 100.0 & 100.0 & 7.96 \\
\hline \multirow{3}{*}{$\begin{array}{l}\text { Cyprodinil + } \\
\text { fludioxonil }\end{array}$} & 1000 & 54.17 & 66.67 & 83.33 & 75.00 & 83.33 & 95.83 & 8.05 & 62.50 & 70.83 & 83.33 & 75.00 & 91.67 & 100.0 & 8.18 \\
\hline & 150 & & 87.50 & 91.67 & 87.50 & 91.67 & 100.0 & 7.33 & 91.67 & 91.67 & 95.83 & 91.67 & 95.83 & 100.0 & 7.05 \\
\hline & 2000 & 95. & 100.0 & 100.0 & 95.83 & 100.0 & 100.0 & 6.25 & 95.83 & 100.0 & 100.0 & 100.0 & 100.0 & 100.0 & 7.36 \\
\hline \multirow{3}{*}{ BHA } & 1000 & 8.33 & 41.67 & 33.33 & - & - & - & 7.93 & 12.50 & 45.83 & 45.83 & - & - & - & 6.26 \\
\hline & 1500 & 12.50 & 50.00 & 37.50 & - & - & - & 8.18 & 20.83 & 50.00 & 45.83 & - & - & - & 7.42 \\
\hline & 2000 & & 58.33 & 54.17 & - & 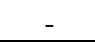 & - & 6.23 & 25.00 & 54.17 & 50.00 & - & - & - & 7.63 \\
\hline S.D & & 7.88 & 7.93 & 8.05 & 8.13 & 8.22 & 10.14 & - & 7.56 & 7.56 & 8.25 & 7.95 & 6.43 & 9.22 & 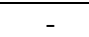 \\
\hline
\end{tabular}

Aldunate et al. (1992) reported that the synergistic effect of BHA is not fully clear, however, it has been shown to have a direct effect on the mitochondrial electron chain of trypanosomes, thus inhibiting respiration. BHA increases leakage of sugars, amino acids and proteins from Fusarium sp. The leakage of sugars, amino acids and proteins may be an indication of mycelial membrane disruption by the BHA as an initial step in inhibition of the tested fungi in vitro. This effect may increase the fungitoxic action of the fungicides against the fungal growth (Thompson, 1996). Additionally, Khan et al. (2001) cited that BHA may make membranes of Colletotrichum musae more leaky and allowing more fungicide into the fungal cells. Simonetti et al. (2002 and 2003) suggested that antioxidants such as BHA appear to promote fluconazole activity by increasing cell membrane permeability leading to the leakage of cellular enzymes. The protective properties of antioxidants are probably due to their ability to act as superoxide anion scavengers, thereby protecting cell membranes from mycotoxin-induced damage (Atroshi et al., 2002). Baider and Cohen (2003) reported that antioxidants may enhance host resistance to fungal infections. Also, the synergistic action of BHA may be attributed to the prevention or delaying the oxidation of the fungicides within the fungal cells which may reduce their fungitoxic action (Ali, 2008). It is known that the synergistic action is more pronounced when components of the mixture had different modes of action (Gisi, 1996).

Generally, addition of BHA to low concentrations of fungicides may increase their fungitoxic action. Also, the fungicidal activity of fungicides and BHA may be significantly increased when applied under definite $\mathrm{pH}$ values. The purpose to use BHA-fungicides mixtures is to reduce the fungicide concentrations and hence minimize residues on fruits as well as the chemical costs.

\section{REFERENCES}

Abdel-Monaim, M.F. and Ismail, M.E. (2010): The use of antioxidants to control root rot and wilt diseases of pepper. Not Sci. Biol., 2: 46-55.

Aldunate, J.; Coloma Torres, I.; Spenser, P.; Morello, A.; Oieda, J.M. and Repetto, Y. (1992): Effects of 2(3)-tert-butyl-4-hydroxyanisole (BHA) on in situ mitochondria of Trypanosoma cruzi. FEBS Letters 303, 73-76.

Ali, W.M.S.A (2008): Integrated control of some tomato diseases. Ph.D. Thesis, Fac. of Agric., Al-Azhar Univ.

Arroyo, M (2003): Natural antifungal systems for prevention of mould spoilage in bakery products. Ph.D. Thesis, Applied Mycology group, Institute of bioscience and technology, Cranfield university, 166-168.

Atroshi, F.; Rizzo, A.; Westermarck, T. and Ali-Vehmas, T. (2002): Antioxidant nutrients and mycotoxins. Toxicology, 180 (2): 151-167.

Baider, A. and Cohen, Y. (2003): Synergistic interaction between BABA and mancozeb in controlling Phytophthora infestans in potato and tomato and Pseudoperonospora cubensis in cucumber. Phytoparasitica, 31 (4): 399-409. 
Cerdan-Calero, M.; Sendra, J.M. and Sentandreu, E. (2012): Gas chromatography coupled to mass spectrometry analysis of volatiles, sugars, organic acids and amino acids in Valencia late orange juice and reliability of the automated mass spectral deconvolution and identification system for their automatic identification and quantification. J. Chromatogr. A, 1241: 84-95.

Eckert, J.W. and Eaks, I.L. (1989): Postharvest disorders and diseases of citrus fruits. Pages 180-260 in: The Citrus Industry: Volume V. W. Reuther, C.E. Calavan, and G.E. Carmen, eds. University of California, Division of Agriculture and Natural Resources, Oakland.

Eckert, J.W. and Kolbezen, M.J. (1977): Influence of formulation and application method on the effectiveness of benzimidazole fungicides for controlling postharvest diseases of citrus fruits. Neth. J. Pl. Path. 83: 343-352.

Errampalli, D. and Crnko, N. (2004): Control of blue mold caused by Penicillium expansum on apples "Empire" with fludioxonil and cyprodinil. Canadian Journal of Plant Pathology, 26: 70-75.

Finney, D.I. (1971): Probit analysis. Cambridge University Press, London, $450 \mathrm{p}$.

Ghadimipour, R. and Sedigh-Eteghad, S. (2015): Inhibitory effects of butylated hydroxyanisole on growth of molds and yeasts at different $\mathrm{pH}$ conditions and different $\mathrm{NaCl}$ concentrations. J. Med. J., 49 (3): 139-145.

Giridhar, P. and Reddy, S.M. (2001): Phenolic antioxidants for the control of some mycotoxigenic fungi. Journal of Food Science and Technology Mysore, 38 (4): 397-399.

Gisi, U. (1996): Synergistic interaction of fungicides in mixtures. Phytopathology, 86: 1273-1279.

Griffin, D.H. (1994): Spore dormancy and germination. Page 389 in: Fungal Physiology, $2^{\text {nd }}$ ed. Wiley Liss, Inc., New York.

Guo, J.; Brosnan, B.; Furey, A.; Arendt, E.K.; Axel, C. and Coffey, A. (2014): Anti - oomycete potential of Lactobacillus amylovorus JG2 against the potato blight pathogen Phytophthora infestans. Int. J. Curr. Microbiol. App. Sci., 3 (1): 630-647.

Helalia, A.R. and Sameer, W.M. (2014): Efficacy of fungicides - sodium bicarbonate combination on citrus postharvest green mould disease. Middle East J. Agric. Res., 3 (2): 240-247.

Holmes, G.J. and Eckert, J.W. (1999): Sensitivity of Penicillium digitatum and $P$. italicum to postharvest citrus fungicides in California. Phytopathology, 89: 716-721.

Hwang, L. and Klotz, L. J. (1938): The toxic effect of certain chemical solutions on spores of Penicillium italicum and P. digitatum. Hilgardia, 12 (1): 1-38.

Jae-Wook, H.; Seong-Chan, L.; Yang-Bin, I.; Dong-Hwan, K.; Sang-Wook, K. and Kwang-Sik, K. (2001): Protective effect of liminoctadine tris (albesilate) and kresoxim - methyl fungicides to citrus postharvest diseases caused by Penicillium spp. The Korean Journal of Pesticide Science, 5 (2): 37-44.
Karaoglanidis, G.S.; Markoglou, A.N.; Bardas, G.A.; Doukas, E.G.; Konstantinou, S. and Kalampokis, J.F. (2011): Sensitivity of Penicillium expansum field isolates to tebuconazole, iprodione, fludioxonil and cyprodinil and characterization of fitness parameters and patulin production. Int. J. Food Microbiol., 145 (1): 195-204.

Khalifa, H.M.S. and Sameer, W.M. (2014): Control of the green mold of orange using fungicides alone and in combination with antioxidants. Middle East J. App. Sci. 3(2): 351-358.

Khan, S.H.; Aked, J. and Magan, N. (2001): Control of the anthracnose pathogen of banana (Colletotrichum musae) using antioxidants alone and in combination with thiabendazole or imazalil. Plant Pathology, 50: 601-608.

Malandrakis, A.A.; Vattis, K.N.; Markoglou, A.N. and Karaoglanidis, G.S. (2017): Characterization of boscalid - resistance conferring mutations in the SdhB subunit of respiratory complex II and impact on fitness and mycotoxin production in Penicillium expansum laboratory strains. Pesticide Biochemistry and Physiology, 138: 97-103.

Palou, L. (2014): Penicillium digitatum, Penicillium italicum (green mold, blue mold). In: Bautista Banos, S. (Ed.), Postharvest Decay. Control Strategies. Academic Press, Elsevier Inc., London, UK, pp. 45-102.

Pitt, J.I. and Hocking, A.D. (1997): Fungi and food spoilage. 2nd ed. London, Blackie Academic \& Professional , 1-12.

Prusky, D.; McEvoy, J.L.; Safiner, R.; Conway, W.S. and Jones, R. (2004): Relationship between host acidification and virulence of Penicillium spp. on apple and citrus fruit. Phytopathology, 94: 44-51.

Rajkumar, M.; Lee, K.J. and Freitas, H. (2008): Effects of chitin and salicylic acid on biological control activity of Pseudomonas spp. against damping-off of pepper. South African J. of Botany, 74: 268-273.

Sallato, B.V.; Torres, R.; Zoffoli, J.P. and Latorre, B.A. (2007): Effect of boscalid on postharvest decay of strawberry caused by Botrytis cinerea and Rhizopus stolonifer. Spanish Journal of Agricultural Research, 5: 67-78.

Samoucha, Y. and Cohen, Y. (1989): Field control of potato late blight by synergistic fungicidal mixtures. Plant disease 73:751-753.

Sanchez-Torres, P. and Tuset, J.J. (2011): Molecular insights into fungicide resistance in sensitive and resistant Penicillium digitatum strains infecting citrus. Postharvest Biology and Technology, 59: 159-165.

Serey, R.A.; Torres, R. and Latorre, B.A. (2007): Pre- and post- infection activity of new fungicides against Botrytis cinerea and other fungi causing decay of table grapes. Cien. Inv. Agr. 34 (3): 215-224.

Simonetti, G.; Simonetti, N. and Villa, A. (2003): Increase of activity of tioconazole against resistant microorganisms by the addition of butylated hydroxyanisole. International Journal of Antimicrobial Agents, 22 (4): 439-443. 
Simonetti, G.; Villa, A. and Simonetti, N. (2002): Enhanced contact activity of fluconazole in association with antioxidants against fluconazoleresistant organisms. Journal of Antimicrobial Chemotherapy, 50 (2): 257-259.

Smilanick, J.L.; Mansour, M.F.; Margosan, D.A.; Mlikota Gabler, F. and Goodwine, W.R. (2005): Influence of $\mathrm{pH}$ and $\mathrm{NaHCO} 3$ on the effectiveness of imazalil to inhibit germination of spores of Penicillium digitatum and to control postharvest green mold on citrus fruit. Plant Dis., 89: 640-648.

Smilanick, J.L.; Mansour, M.F.; Mlikota Gabler, F. and Goodwine, W.R. (2006): The effectiveness of pyrimethanil to inhibit germination of Penicillium digitatum and to control citrus green mold after harvest. Postharvest Biology and Technology, 42: 75-85.

Smilanick, J.L.; Mansour, M.F.; Mlikota Gabler, F. and Sorenson, D. (2008): Control of postharvest green mold and sour rot by potassium sorbate combined with heat and fungicides. Postharvest Biol. Technol. 47: 226-238.

Snedecor, G.W. and Cochran, W.G. (1969): Statistical method. The lowa Status Uni. Press, Ames, IA593pp.

Thompson, D.P. (1996): Inhibition of growth of mycotoxigenic Fusarium species by butylated hydroxyanisole and/or carvacrol. Journal of Food Protection, 59 (4): 412-415.
Thompson, D.P. (1997): Effect of phenolic compounds on mycelial growth of Fusarium and Penicillium species. Journal of Food Protection, 60 (10): 12621264.

Thompson, D.P.; Metevia, L. and Vessel, T. (1993): Influence of $\mathrm{pH}$ alone and in combination with phenolic antioxidants on growth and germination of mycotoxigenic species of Fusarium and Penicillium. Journal of Food Protection, 56 (2): 134-138.

Turkkan, M. and Erper, I. (2014): Evaluation of antifungal activity of sodium salts against onion basel rot caused by Fusarium oxysporum f.sp. cepae. Plant Protect. Sci., 50: 19-25.

Zhang, C.Q.; Yuan, S.K.; Sun, H.Y.; Qi, Q. Z.; Zhou, M.G. and Zhu, G.N. (2007): Sensitivity of Botrytis cinerea from vegetable greenhouses to boscalid. Plant Pathology, 56: 646-653.

Zhang, C.Q.; Zhang, Y. and Zhu, G.N. (2008): The mixture of kresoxim - methyl and boscalid, on excellent alternative controlling grey mould caused by Botrytis cinerea. Annals of Applied Biology, 153: 205-213.

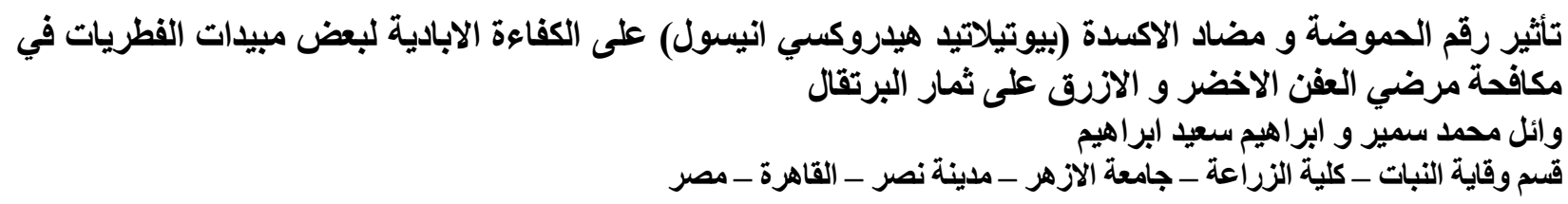

يعتبر مرضي العفن الاخضر و الازرق المتسببين عن فطري بنسليوم ديجيتاتم و بنسليوم اتاليكام من الامر اض الرئيسية التي تسبب عفن

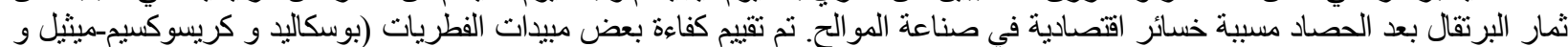

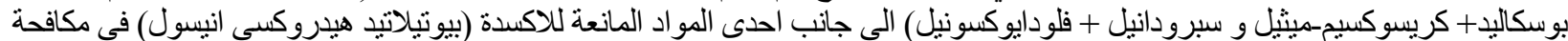

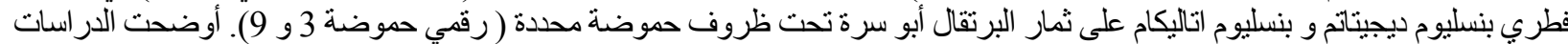

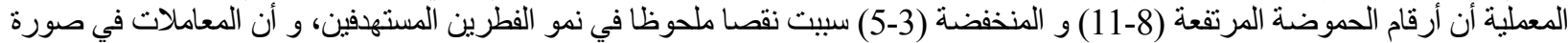

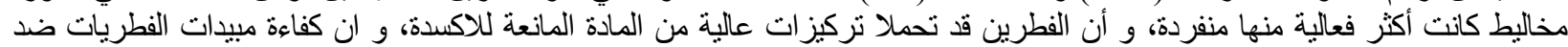

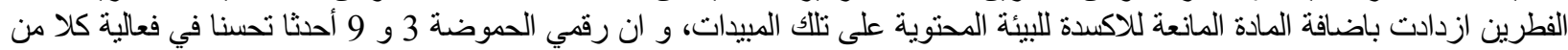

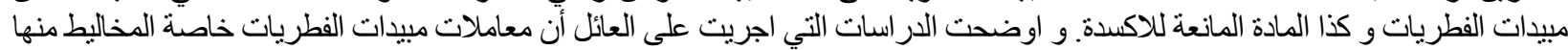

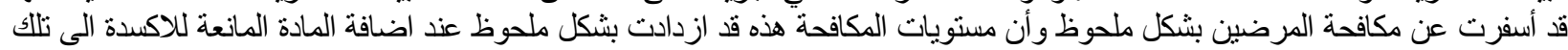
المبيدات أو عند اجر اء المكافحة في ظل رقمي الحموضة 3 و و 9. 